\title{
Peta Perkembangan Literatur Hadith di Pesantren Kabupaten Banyumas
}

\author{
Farah Nuril Izza ${ }^{1}$
}

\begin{abstract}
Pesantren as an indigenous educational institution born from the tradition of Indonesia has contributed significantly to the development of its graduates in scientific and leadership field. Pesantren's scientific tradition contained in its literature has been able to form a system of thought with special characters. However, studies on hadith and the development of its literature, specifically at pesantren, are still rarely carried out. Meanwhile, the concern on hadith in Indonesia has experienced a significant growth since the $20^{\text {th }}$ century after the emergence of the reform movement as the result of modernism. It is characterized by the use of hadith literature as the curriculum at the mosque, school or pesantren. In this era, pesantren faces the social reality that is always changing with the changing time. As the oldest educational institution in Indonesia, pesantren has a strategic position to respond to these changes by developing a curriculum and literature.

This article studies the development of hadith studies at Pesantrens in Banyumas. Most pesantrens still have not used the hadith literature with new ideas or adopted methodology oriented literature. Literatures that are used by most pesantrens are books written by classic scholars called the yellow book, although some pesantrens with modern and comprehensive types have added contemporary literature in the curriculum.
\end{abstract}

\begin{abstract}
Abstrak
Pesantren sebagai lembaga pendidikan lokal yang lahir dari budaya Indonesia telah memberikan kontribusi bagi perkembangan lulusannya dalam bidang keilmuan dan kepemimpinan. Tradisi keilmuan Pesantren yang tercakup dalam literaturnya telah mampu membentuk suatu sistem pemikiran dengan cirinya yang khas. Akan tetapi, kajian terhadap hadith dan perkembangan literaturnya masih jarang dilakukan. Sementara, perhatian terhadap hadith di Indonesia telah mengalami pertumbuhan yang cukup signifikan di abad keduapuluh setelah
\end{abstract}

${ }^{1}$ Dosen IAIN Purwokerto. E-mail: farah.izza28@gmail.com. 
munculnya gerakan pembaharuan sebagai akibat dari modernisme. Ini ditandai dengan penggunaan literatur hadith sebagai kurikulum di masjid-masjid, sekolah-sekolah atau pesantrenpesantren. Pada masa ini, pesantren menghadapi realitas sosial yang selalu berubah sesuai dengan perubahan zaman. Sebagai salah satu lembaga pendidikan tertua di Indonesia, pesantren memiliki posisi yang strategis untuk merespon perubahan ini dengan mengembangkan kurikulum dan literat ur hadith.

Artikel ini mengkaji perkembangan kajian hadith di Pesantren Banyumas. Kebanyakan pesantren masih belum menggunakan literatur hadith dengan ide-ide baru atau menggunakan metodologi yang berorientasi kekayaan literatur. Literatur yang digunakan kebanyakan pesantren adalah buku-buku yang ditulis para ulama klasik yang biasa disebut dengan buku kuning, walaupun sebagian pesantren dengan tipe modern dan terpadu telah menambahkan literatur dan kurikulum kontemporer.

Keywords: pesantren salaf, khalaf dan komprehensif; kitab kuning, literatur hadith klasik dan kontemporer.

\section{Pendahuluan}

Salah satu tradisi agung (great tradition) di Indonesia adalah tradisi pengajaran agama Islam di pesantren maupun lembaga-lembaga pendidikan serupa di Jawa dan semenanjung Malaya. ${ }^{2}$ Abdurrahman Wahid mendefinisikan pesantren sebagai sebuah institusi pendidikan yang berada di bawah pimpinan seorang atau beberapa kiai yang dibantu oleh santri senior dengan beberapa orang anggota keluarga. Pesantren menjadi bagian yang sangat penting dalam kehidupan seorang kiai sebab ia merupakan tempat untuk mengembangkan dan melestarikan tradisi. ${ }^{3}$

Menurut Nurcholish Madjid, pesantren merupakan sebuah lembaga pendidikan yang indigenous lahir dari tradisi keindonesiaan. Sebagai sebuah lembaga pendidikan, pesantren yang sudah ada sejak lama dipandang telah memberikan kontribusi yang signifikan terhadap perkembangan lulusannya yang memiliki kiprah dalam bidang keilmuan maupun kepemimpinan. ${ }^{4} \mathrm{Hal}$ ini senada

${ }^{2}$ Martin van Bruinessen, Kitab Kuning Pesantren dan Tarekat: Tradisi-tradisi Islam di Indonesia (Bandung: Mizan, 1995).

${ }^{3}$ Abdurrahman Wahid, Bunga Rampai Pesantren (Jakarta: Dharma Bhakti, 1978), 67.

${ }^{4}$ Nurcholish Madjid, Bilik-Bilik Pesantren Sebuah Potret Perjalanan (Jakarta: Paramadina, 1997). 
dengan apa yang disampaikan oleh Mansur, jika dilihat dari spectrum pembangunan bangsa, pondok pesantren selain sebagai lembaga pendidikan Islam juga sebagai bagian dari infrastruktur masyarakat yang secara sosiokultural ikut berkiprah dalam proses pembentukan kesadaran masyarakat untuk memiliki idealisme bagi kemajuan bangsa dan negaranya. ${ }^{5}$

Literatur-literatur pesantren yang sebagian besar tertuang melalui kitab kuning merupakan representasi dari pemikiran keilmuan dengan setting sejarah tertentu. Tradisi keilmuan pesantren telah mampu membentuk sistem pemikiran dengan karakter khusus. Model pemikiran pesantren menjadi jalinan sistem yang tidak hanya berlaku bagi kyai saja namun juga bagi santrinya. Kalangan masyarakat pesantren masih tetap kukuh berkeyakinan bahwa ajaran-ajaran yang dikandung dalam kitab kuning tetap merupakan pedoman hidup yang relevan. Mereka mempercayai bahwa sumber ajaran mereka adalah al-Qur'ān dan sunnah Rasulullah, namun menjadikan interpretasi dan penjelasan ulama dalam kitab kuning sebagai pedoman. ${ }^{6}$

Hadith sebagai sebuah peradaban teks dalam ajaran Islam merupakan sumber ajaran dan rujukan tentang berbagai konsep selain al-Qur'ān. Hadith dapat diterjemahkan secara tekstual maupun kontekstual. Penggunaan literatur hadith yang bervariatif memiliki pengaruh yang besar terhadap perkembangan pemikiran pembacanya khususnya kalangan pesantren. Di era sekarang, pesantren senantiasa menghadapi realitas sosial yang selalu berubah seiring dengan perubahan dan perkembangan zaman. Sebagai lembaga pendidikan yang tertua di Indonesia pesantren memiliki posisi yang strategis untuk merespon perubahan-perubahan tersebut; salah satunya adalah dengan mengembangkan kurikulum dan literatur yang digunakan. Produk pesantren juga dikonstruksi dengan harapan memiliki kemampuan yang tinggi dalam merespon perubahan tersebut baik dalam ranah nasional maupun internasional serta mampu membentuk manusia yang memiliki kesadaran tinggi akan ajaran Islam yang bersifat komprehensif.

Tulisan ini difokuskan pada peta perkembangan literatur hadith di pesantren hingga saat ini dengan mengambil sampel pesantren-pesantren yang terdapat di wilayah kabupaten Banyumas serta faktor yang mempengaruhi perkembangan tersebut. Tulisan ini diharapkan mempunyai manfaat baik secara teoritis maupun praktis. Secara teoritis tulisan ini dapat memberikan

5 Mansur, Moralitas Pesantren, Meneguk Kearifan dari Telaga Kehidupan (Yogyakarta: Safiria Insania Press, 2004), 7-8.

${ }^{6}$ Sahal Mahfudz, Pesantren Mencari Makna (Jakarta: Pustaka Ciganjur, 1999), 102. 
sumbangan terhadap perkembangan literatur hadith di Indonesia secara umum maupun pesantren secara khusus beserta faktor yang melatarbelakanginya. Secara praktis dengan mengetahui perkembangan literatur hadith di pesantren, diharapkan dapat diketahui nalar pesantren dan terdapat upaya untuk merekonstruksi pemikiran yang ada di kalangan pesantren sehingga mereka memiliki pemahaman komprehensif serta tercipta dinamisasi pemikiran di dunia Islam.

\section{Dinamika Perkembangan Pesantren}

Terdapat dua pendapat tentang sejarah kemunculan pesantren menurut Imam Tholkhah dan Ahmad Barizi. Pertama, pesantren telah ada sejak abad XVI M dengan ditandai adanya beberapa karya Jawa klasik seperti Serat Cebolek dan Serat Centini yang berisi keterangan bahwa sejak abad XVI M tersebut telah banyak dijumpai beberapa lembaga di Indonesia yang mengajarkan berbagai macam kitab Islam klasik dalam berbagai bidang, seperti fikih, akidah dan lainnya. Lembaga-lembaga tersebut juga menjadi pusat penyiaran Islam. ${ }^{7}$ Sebelum munculnya lembaga penyiaran Islam tersebut, Abdurrahman Mas'ud dalam bukunya mengungkapkan pada abad ke XV hingga abad ke XVI kaum muslim Jawa memiliki kecenderungan menjadikan Mekah sebagai kiblat penyebaran ilmu pengetahuan Islam standar. Sunan Bonang misalnya, diduga telah mentransfer ajaran-ajaran Imam Syafi'i dan al-Ghazali melalui karya-karyanya dalam bahasa Jawa. ${ }^{8}$

Pendapat kedua mengatakan bahwa pesantren muncul dan mengadopsi sistem pendidikan Hindu Budha pada abad ke XVIII M serta mengalami perkembangan yang pesat hingga terjadi banyak perubahan di berbagai sisi sebagai dampak dari modernisme dan globalisasi pada abad ke XX M.

Marwan Saridjo justru mengungkapkan bahwa pesantren telah hadir dan berkembang di wilayah Nusantara seiring dengan penyebaran Islam di Indonesia. Pesantren ada sejak akhir abad ke XIV M atau awal abad ke XV M didirikan pertama kali oleh Maulana Malik Ibrahim kemudian dikembangkan lebih jauh oleh Sunan Ampel. ${ }^{9}$

Lebih jauh, Karel A. Steenbrink menguraikan bahwa pada awalnya pondok pesantren hanyalah lembaga pendidikan agama Islam yang dilaksanakan

${ }^{7}$ Imam Tholkhah dan Ahmad Barizi, Membuka Jendela Pendidikan, Mengurai Akar Tradisi (Jakarta: PT. Raja Grafindo Persada, 2004), 52.

${ }^{8}$ Abdurrahman Mas'ud, Intelektual Pesantren: Perhelatan Agama dan Tradisi (Yogyakarta: LKiS, 2004), 78.

${ }^{9}$ Marwan Saridjo et. al., Sejarah Pondok Pesantren di Indonesia (Jakarta: Dharma Bakti, 1982), 22. 
secara non klasikal. Kyai mengajarkan kitab-kitab seperti tajwid, tafsir alQur'ān, akidah, ilmu kalam, fikih ataupun ushul fikih, hadith atau ilmu hadith, bahasa Arab beserta gramatikanya, sejarah Islam, mantiq, tasawuf dan lainnya. ${ }^{10}$

Dilihat dari tipenya berdasarkan keilmuan, pesantren dibagi menjadi tiga: Pertama, pesantren tradisional (salafiyyah) yang merupakan pesantren yang masih mempertahankan keasliannya dengan hanya mengajarkan kitab-kitab klasik karya ulama abad 15 dengan menggunakan Bahasa Arab. Nalar kritis belum dikembangkan, kitab-kitab tersebut hanya dikaji isinya untuk mendapatkan pemahaman yang dimaksud oleh kitab. Santri mempercayai sepenuhnya apa yang disampaikan oleh kyai melalui kitab tersebut. Kedua, pesantren modern (khalafiyyah) yang merupakan pesantren yang mengintegrasikan antara sistem klasikal dan sekolah ke dalam pondok pesantren. Kajian kitab klasik tidak terlalu menonjol, bahkan sebagian pondok pesantren menjadikannya sebagai pelengkap. Ketiga, pondok pesantren komprehensif yang merupakan pondok pesantren yang menggabungkan antara sistem pendidikan tradisional dan modern. Kitab kuning tetap dikaji dan menjadi rujukan namun sistem pendidikan formal tetap terus dikembangkan. ${ }^{11}$

Zamakhsyari Dhofier membagi pondok pesantren menjadi dua tipe besar yaitu tipe klasik yang inti dari pengajarannya adalah mengajarkan kitab Islam klasik, sedangkan sistem madrasah ditetapkan untuk memudahkan sistem yang digunakan tanpa memasukkan pengetahuan umum dan tipe baru atau khalaf merupakan pesantren yang memasukkan pelajaran umum dalam kurikulum madrasah atau menyelenggarakan tipe sekolah umum hingga perguruan tinggi di lingkungannya. ${ }^{12}$ Husni Rahim memetakan pondok pesantren dalam dua kategori yaitu pesantren salafiyah dan pesantren khalafiyah yang mengadopsi sistem pendidikan klasikal dengan kurikulum terintegrasi pengetahuan umum. ${ }^{13}$

Menteri Agama melalui peraturan No. 3 tahun 1979 membagi pesantren ke dalam beberapa bentuk. Pertama pondok pesantren tipe A di mana santri belajar dan berdomisili di asrama lingkungan pondok pesantren dengan model pendidikan tradisional. Kedua pondok pesantren tipe B yaitu pondok pesantren yang menyelenggarakan pengajaran secara klasikal dan pengajaran oleh kyai

${ }^{10}$ Karel A. Steenbrink, Pesantren, Madrasah, Sekolah: Pendidikan dalam Kurun Modern (Jakarta: LP3ES, 1986), 12.

${ }^{11}$ Mastuhu, Dinamika Sistem Pendidikan Pesantren (Jakarta: INIS, 1994), 61.

${ }^{12}$ Zamakhsyari Dhofier, Tradisi Pesantren: Studi Pandangan Hidup Kiai dan Visinya Mengenai Masa Depan Indonesia (Jakarta: LP3ES, 2011), 75-76.

${ }^{13}$ Husni Rahim, Madrasah dalam Politik Pendidikan Indonesia (Ciputat: PT Logos Wacana Ilmu, 2005), 76. 
bersifat aplikatif pada waktu-waktu tertentu. Santri tinggal di asrama lingkungan pondok pesantren. Ketiga adalah pondok pesantren tipe $\mathrm{C}$ yang hanya merupakan asrama tempat domisili santri. Mereka menempuh jenjang pendidikan formal di luar pesantren baik madrasah maupun sekolah umum, kyai hanya merupakan pengawas dan pembina mental para santri. Keempat pondok pesantren tipe D yang menyelenggarakan sistem pondok pesantren terintegrasi dengan sekolah atau madrasah. ${ }^{14}$

Ahmad Qadri Abdillah Azizy membagi pesantren atas dasar kelembagaan dengan sistem pengajarannya ke dalam lima kategori. Pertama, pesantren yang menyelenggarakan pendidikan formal dengan menerapkan sistem pendidikan nasional baik berupa madrasah maupun sekolah umum. Kedua, pesantren yang menyelenggarakan pendidikan dalam bentuk madrasah serta mengajarkan ilmu umum meski tidak menerapkan kurikulum nasional. Ketiga, pesantren yang hanya mengajarkan ilmu agama dalam bentuk madrasah diniyah. Keempat, pesantren yang menjadi tempat untuk pengajaran dan penyiaran agama Islam. Kelima, pesantren hanya sebagai tempat domisili bagi santri yang belajar di sekolah ataupun perguruan tinggi. ${ }^{15}$

Pesantren dari waktu ke waktu terus mengalami perkembangan. Banyak pesantren yang berusaha untuk menyesuaikan tuntutan zaman dengan memasukkan pengetahuan umum ke dalam kurikulumnya, meski pengajaran kitab klasik masih menjadi prioritas utama. Namun masih ada beberapa pesantren yang tetap mempertahankan ciri khasnya dengan hanya mengajarkan kitab kuning tanpa menambah literatur umum.

\section{Literatur Hadīth di Indonesia dari Masa ke Masa}

Kajian hadith dan perkembangan literaturnya secara spesifik di pesantren masih jarang dilakukan. Howard M. Federspiel berpendapat tidak berkembangnya kajian hadith di Indonesia. Perhatian tentang hadith di Indonesia baru mengalami perkembangan yang cukup signifikan pada abad ke 20 setelah munculnya gerakan pembaharuan sebagai dampak dari modernisme. Hal tersebut ditandai dengan dijadikannya literatur-literatur hadith sebagai bahan ajar kurikulum baik di surau, madrasah maupun pesantren, seperti yang disebutkan oleh Mahmud Yunus dan Martin van Bruinessen.

14 Departemen Agama RI Direktorat Jenderal Kelembagaan Agama Islam, Direktorat Pendidikan Keagamaan dan Pondok Pesantren Proyek Peningkatan Pendidikan Luar Sekolah pada Pondok Pesantren, Pola Pengembangan Pondok Pesantren, (Jakarta: 2003), 24-25.

${ }^{15}$ Mujamil Qomar, Pesantren: Dari Transformasi Menuju Demokratisasi Institusi (Jakarta: Erlangga, t.th), 28. 
Perkembangan kajian hadith di Indonesia bisa dikatakan hampir sama dengan perkembangan kajian tafsir. Pada awalnya digunakan sebagai pendukung atau referensi dari amalan-amalan fikih dan tasawuf yang merupakan aplikasi ibadah ritual. Sejalan dengan adanya modernisasi dan pembaharuan Islam, maka banyak ulama yang menekuni hadith lebih mendalam dan menulis karya dalam bidang tersebut, diantaranya:

Pertama, Nuruddin al-Raniri. ${ }^{16}$ Ia mengumpulkan hadith dalam karyanya

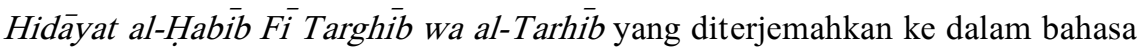
melayu. Dalam kitabnya, ia menginterpretasikan dan mengkoneksikan hadithhadith dengan ayat al-Qur'ān untuk mendukung argumen yang ada dalam hadith. ${ }^{17}$

Kedua, Abdul Rauf al-Singkili. ${ }^{18}$ Ia menulis dua karya dalam bidang hadith yaitu: penafsiran mengenai Hadith Arba'in karya al-Nawawi yang ditulis atas permintaan Sulatnah Zakiyat al-Din, al-Mau'izah al-Badi' $a h$ yaitu sebuah koleksi hadith Qudsi.

Ketiga, Kiai Mahfuz Termas. Di Jawa kitab Saḥị̆ al-Bukhārī mungkin sudah dibaca oleh beberapa Kiai namun tidak diajarkan secara meluas. Ia mengajarkanya secara luas dan menyusun kitab hadith dengan judul Manhaj Dhawī al-Nazar.

Keempat, Hasyim Asy'ari. Ia membawa tradisi kitab Hadith Sahịh alBukhäri ke Indonesia sehingga pesantrenya menjadi pondok hadith paling

16 Nuruddin al-Raniri, Nama lengkapnya, Nuruddin Muhammad bin Ali bin Hasanji Al-Hamid (atau Al-Syafi'i Al-Asyary Al-Aydarusi Al-Raniri (untuk berikutnya disebut Al-Raniri). la dilahirkan di Ranir (Randir), sebuah kota pelabuhan tua di Pantai Gujarat, sekitar pertengahan kedua abad XVI M. Ibunya seorang keturunan Melayu, sementara ayahnya berasal dari keluarga imigran Hadhramaut (Al-Attas: 1199 M). Seperti ketidakpastian tahun kelahiran, asal usul keturunan Al-Raniri pun memuat dua kemungkinan. Kemungkinan pertama, nenek moyangnya adalah keluarga Al-Hamid dari Zuhra (salah satu dari sepuluh keluarga Quraisy). Sementara kemungkinan yang lain AlRaniri dinisbatkan pada Al-Humayd, orang yang sering dikaitkan dengan Abu Bakr 'Abd Allah b. Zubair Al-As'adi Al-Humaydi, seorang mufti Makkah dan murid termasyhur AlSyafi'i. Lihat S. M. N. al-Attas, Raniry and Wujudiyah of 17th Century Acheh (Singapore, MBRAS, 1966), 12.

17 Musyrifah Sunanto, Sejarah Peradaban Islam Indonesia (Jakarta: PT. Raja Grafindo Persada, 2007), 298.

${ }^{18}$ Abd al-Rauf al-Singkili (Singkel, 1035 H/1615 M-Banda Aceh, 1105 H/1693 M). Ulama besar dan tokoh tasawuf dari Aceh yang pertama kali membawa dan mengembangkan Tarekat Syattariah di Indonesia. Nama aslinya adalah Abdul Rauf alFansuri. Ia mengunjungi pusat-pusat pendidikan dan pengajaran agama di sepanjang jalur perjalanan haji antara Yaman dan Mekkah. Ia kemudian bermukim di Mekkah dan Madinah untuk menambah pengetahuan tentang ilmu al-Qur'ān, ḥadith, fiqih, dan tafsir, serta mempelajari tasawuf. 
terkenal di Jawa. Ia mengarang kitab Hadith Arba'īn, al-Risālah al-Jämi'ah dan al-Nür al-Mubin fï ahabbat Sayyid al-Mursalin. ${ }^{19}$

Berkaitan dengan penyebaran kitab hadith, perhatian yang besar terhadap hadith di Indonesia telah berkembang pada abad ke-20 ditandai dengan adanya kitab-kitab hadith yang dijadikan bahan ajar kurikulum di surau, madrasah dan pesantren. Mahmud Yunus mencatat bahwa pada tahun 1900-1908 kitab hadith sudah diajarkan di berbagai surau yang menjadi cikal bakal lahirnya madrasah di Sumatera. Kitab-kitab yang diajarkan adalah Hadith Arba'in karya al-Nawawi, Sahih al-Bukhāri, Șahih Muslim, Faṭ̣ al-Bārì Bi Sharh Sahīh al-Bukhārī karya Ibnu Hajar al-Asqalani dan lainya di bidang materi hadith. ${ }^{20}$

Tidak jauh dari hasil pengamatan Mahmud Yunus, penelitian Martin van Bruinessen di pesantren-pesantren dan madrasah-madrasah pada beberapa provinsi di Indonesia sampai tahun 1990-an menyebutkan daftar literatur hadith dan Ilmu Muștalah Hadith yang lebih lengkap dari sisi penyebaran dan penggunaannya. $^{21}$

Selanjutnya, dilihat dari segi literatur yang digunakan, kurikulum IAIN terutama sejak 1970-an jauh lebih kaya daripada literatur yang digunakan di pesantren dan madrasah. Di bidang ilmu hadith, literatur tersebut tidak hanya bersentuhan dengan teori kritik hadith pada tingkat dasar, tetapi sudah pada tingkat lanjutan. Begitu pula, materi hadithnya telah menggunakan hampir seluruh kitab hadith primer dan sekaligus turunannya. Literatur syarah juga menjadi bahan acuan dalam kurikulum ini. Di antara kitab syarah yang digunakan adalah Fatḥ al-Bāri karya Ibn Hajar, Sahih Muslim Sharh al-Nawawi, Dalil al-Fälihīn dan kitab lainya. ${ }^{22}$

Bulūgh al-Marām karya Ibnu Hajar diterjemahkan ke dalam bahasa Jawa oleh Subki Masyhadi, dan Subul al-Salām syarah Bulūgh al-Marām karya Muhammad bin Ismail al-Kahlani diterjemahkan ke dalam bahasa Indonesia oleh K. H. Bisri Mustafa. Terdapat juga terjemahan Riyạd al-Sāliḥin dalam bahasa Jawa oleh Asrori Ahmad. Sementara Syaikh Nawawi al-Bantani menulis kitab hadith Tanqīh al-Qaul.

${ }^{19}$ Abdullah bin Yasin al-Pariswani, Ziyat al-Ta lìqāt (t. Tp: Maktabah al-Turāth al-Islāmi, t.th), 6 .

${ }^{20}$ Mahmud Yunus, Sejarah Pendidikan Islam di Indonesia ( Jakarta: Mutiara Sumber Widya, 1985).

${ }^{21}$ van Bruinessen, Kitab Kuning, Pesantren dan Tarekat.

22 "Kurikulum dan Silabus Institut Agama Islam Negeri," (SK. Menteri Agama RI No. 97 tahun 1982), Proyek Pembinaan Prasarana dan Sarana Perguruan Tinggi Agama/IAIN di Jakarta Direktorat Jenderal Pembinaan Kelembagaan Agama Islam Departemen Agama Islam RI, 1983/1984. 
Berikut ini tabel tentang beberapa literatur hadith yang digunakan di Indonesia. $^{23}$

\begin{tabular}{|c|c|}
\hline Judul & Penulis \\
\hline Sahịh al-Bukhärī & Imam al-Bukhari \\
\hline Fath al-Bāri & Ibn Hajar al-‘Asqalani \\
\hline Șahịh Muslim & Imam Muslim \\
\hline Sharh Muslim & Muhyiddin al-Nawawi \\
\hline Sunan Ibn Mäjah & Imam Ibn Majah \\
\hline Sunan al-Turmudhì & Imam al-Turmudzi \\
\hline $\begin{array}{l}\text { Tuhfat al-Ahwadhì bi Sharh Jämi' al- } \\
\text { Turmudhi }\end{array}$ & Al-Mubarakfuri \\
\hline Sunan al-Nasā', & Imam al-Nasai \\
\hline Sunan $A b \bar{u}$ Dāwüd & Imam Abu Dawud \\
\hline Al-Lu'lu' wa al-Marjān & Muhammad Fuad Abdul Baqi \\
\hline Riyāọ al-Ṣāihịin & Muhyiddin al-Nawawi \\
\hline Dalìi al-Fāliḥin & Muhammad bin Alan al-Siddiqi \\
\hline Al-Adab al-Nabawì & Muhammad Abdul Aziz al-Khuli \\
\hline Bulūgh al-Marām & Ibn Hajar al Asqalani \\
\hline Subul al-Salām & $\begin{array}{l}\text { Muhammad bin Isma'il al- } \\
\text { Kahlani }\end{array}$ \\
\hline Ibānat al-Aḥkām & $\begin{array}{l}\text { Ulwi Abbas al-Maliki dan Hasan } \\
\text { Sulaiman al-Nuri }\end{array}$ \\
\hline 'Aun al-Ma'būd & Abu al-Tayyin Abadi \\
\hline Nayl al-Awtär & Muhammad bin Ali al-Syaukani \\
\hline Al-Jämi' al-Saghìr & Jalal al-Din al-Suyuti \\
\hline Miftah al-Khitābah wa al-Wa'd & Muhammad Ahmad al-Adawi \\
\hline
\end{tabular}

${ }^{23}$ Dari beberapa sumber, Asimuni A. Rahman dkk., Kurikulum (Manhaj alDirasah) Fakultas Syariah IAIN Sunan Kalijaga (Yogyakarta: Fakultas Syariah, 1971); Sejarah Institut Agama Islam Negeri tahun 1976-1980, Proyek Pembinaan Prasarana dan Sarana Perguruan Tinggi Agama/IAIN di Jakarta Direktorat Jenderal Pembinaan Kelembagaan Agama Islam Departemen Agama Islam RI, 1986; lihat juga hasil Rumusan Orientasi Pengembangan Kurikulum Sistem Kredit Semester Institut Agama Islam Negeri (IAIN) 20-24 Agustus 1986 di Tugu Bogor (Direktorat Jenderal Pembinaan Kelembagaan Agama Islam Departemen Agama RI, 1986); Topik Inti Kurikulum Nasional Perguruan Tinggi Agama Islam Fakultas Usuluddin (Direktorat Pembinaan Kelembagaan Agama Islam Departemen Agama RI, 1998). 


\begin{tabular}{|c|c|}
\hline Judul & Penulis \\
\hline Mukhtār al-Ahādiṣ al-Nabawiyyah & Ahmad al-Hasyimi Bik \\
\hline Fiqh al-Sïrah & Muhammad al-Ghazali \\
\hline Ma'ālim al-Sunnah & Al-Khattabi \\
\hline Aḥkām al- Aḥkām & Ibn Daqiq al-'Id \\
\hline Al-Hadị al-Nabawì & Fathurrahman \\
\hline Hadis yang Tekstual dan Kontekstual & M. Syuhudi Ismail \\
\hline 2002 Mutiara Hadis & T. M. Hasbi al-Siddiqi \\
\hline Koleksi Hadis Hadis Hukum & T. M. Hasbi al-Siddiqi \\
\hline Ușūl al- Hadith & Muhammad Ajjaj al-Khatib \\
\hline Taisis Mustalah al- Hadith & Mahmud al-Tahhan \\
\hline Usul al-Takhrīj wa Dirāsāt al-Asānìd & Mahmud al-Tahhan \\
\hline Ulum al- Hadith Wa Muṣtalaḥuhu & Subhi al-Salih \\
\hline Tadrib al-Rāwi & Jalaluddin al-Suyuti \\
\hline Manhaj al-Naqd Fi' 'Ulūm al- Hadith & Nuruddin 'Itr \\
\hline Buhuth Fi Tärikh al-Sunnah al-Musarrafah & Akram Diya' al-Amr \\
\hline Metode Takhrīj Hadith & Abu Muhammad 'Abd al-Muhdi \\
\hline Kitāb Ikhtilāf al- Hadith & Al-Syafi'i \\
\hline Ilmu Tabaqat al-Muhaddișin & As'ad tim \\
\hline Al-Nihayah Fi Gharib al- Hadith & Ibnu al-Atsir \\
\hline Al-Faiq Fi Gharib al- Hadith & Al-Zamakhsyari \\
\hline Asbab Wurud al- Hadith & Jalaluddin al-Suyuti \\
\hline Ulum al- Hadith (Muqaddimah Ibn al-Salāh & Ibnu Shalah \\
\hline Tauḍị al-Afkār & $\begin{array}{l}\text { Muhammad bin Isma'il al- } \\
\text { San'ani }\end{array}$ \\
\hline Al-Risālah al-Mustatrafah & Muhammad bin Ja'far al-Kattani \\
\hline Al-Sunnah Qabla al-Tadwin & Muhammad ‘Ajja al-Khatib \\
\hline Dirasat Fi al-Hadith al-Nabawi & Muhammad Musțafa al-A'ẓami \\
\hline Al- Hadith al-Nabawi & Muhammad al-Ṣabbagh \\
\hline Al- Hadith wa al-Muhaddithūn & Muhammad Abu Zahw \\
\hline $\begin{array}{l}\text { Miftah al-Sunnah aw Tärikh Funūn al- } \\
\text { Hadith }\end{array}$ & Abdul Aziz al-Khuli \\
\hline Miftah Kunūz al-Sunnah & A. J. Wensink \\
\hline
\end{tabular}




\begin{tabular}{|l|l|}
\hline \multicolumn{1}{|c|}{ Judul } & \multicolumn{1}{c|}{ Penulis } \\
\hline $\begin{array}{l}\text { Al-Sunnah al-Nabawiyyah Wa Makanatuhā } \\
\text { Fi al-Tashri' al-Islami }\end{array}$ & Mustafa al-Siba'i \\
\hline Ma'rifat Ulüm al- Hadith & Al-Hakim \\
\hline Nuzhat al-Nazar & Ibnu Hajar al Asqalani \\
\hline Al-Mauḍu'ät & Ibnu al-Jauzi \\
\hline
\end{tabular}

Dari tabel di atas dapat diketahui perkembangan literatur hadith yang cukup pesat dimulai sejak abad $20 \mathrm{M}$ dengan diajarkanya literatur-literatur tersebut pada lembaga pendidikan baik di madrasah, pondok pesantren maupun masuk ke dalam silabus perguruan tinggi.

\section{Perkembangan Literatur Hadith di Pesantren Kabupaten Banyumas}

Kabupaten Banyumas memiliki lebih dari 200 pesantren yang tersebar di berbagai wilayah, namun hingga akhir tahun 2014 hanya sekitar 157 pesantren yang memiliki izin operasional dan tercatat di bagian PD Pontren kantor Kementerian Agama Kabupaten Banyumas. 3 pesantren berada di wilayah Lumbir, 4 pesantren berada di wilayah Wangon, 7 pesantren berada di wilayah Jatilawang, 9 pesantren berada di wilayah Rawalo, 3 pesantren berada di wilayah Kebasen, 9 pesantren berada di wilayah Kemranjen, 8 pesantren berada di wilayah Sumpiuh, 8 pesantren berada di wilayah Tambak, 2 pesantren berada di wilayah Kalibagor, 2 pesantren berada di wilayah Banyumas, 3 pesantren berada di wilayah Patikraja, 5 pesantren berada di wilayah Purwojati, 7 pesantren berada di wilayah Ajibarang, 7 pesantren berada di wilayah Pekuncen, 3 pesantren berada di wilayah Pekuncen, 12 pesantren berada di wilayah Cilongok, 4 pesantren berada di wilayah Karanglewas, 12 pesantren berada di wilayah Kedungbanteng, 5 pesantren berada di wilayah Baturaden, 7 pesantren berada di wilayah Sumbang, 8 pesantren berada di wilayah Kembaran, 12 pesantren berada di wilayah Sokaraja, 5 pesantren berada di wilayah Purwokerto Selatan, 3 pesantren berada di wilayah Purwokerto Barat, 3 pesantren berada di wilayah Timur, dan 6 pesantren berada di wilayah Purwokerto Utara.

Peantren yang ada sangat variatif. Jika dilihat dari ilmu yang diajarkan, sebagian besar pesantren termasuk ke dalam pesantren tradisional atau salafiyah yang masih mempertahankan ciri khas dengan mengajarkan kitab klasik atau kitab kuning dengan pendidikan bersifat non formal. Beberapa pesantren termasuk ke dalam pesantren modern yang berusaha mengintegrasikan sistem klasikal dan sekolah formal ke dalam pondok pesantren, sedangkan beberapa 
yang lain termasuk pesantren komprehensif yang menggabungkan sistem pendidikan antara yang tradisional dan modern dengan tetap mengajarkan kitab kuning dan mengembangkan sistem sekolah formal.

Legalisasi ijazah atas pesantren dengan tipe pendidikan non formal dapat dilakukan jika pesantren mengikuti aturan Kementerian Agama mengenai cakupan minimal literatur yang diajarkan. Dalam kajian hadith, literatur yang harus dipelajari adalah Riyạ̣ al-Ṣäliḥīn dan Bulūgh al-Marām. ${ }^{24}$ Riyạ̣ alSăliḥin Min Kalām Sayyid al-Mursalin merupakan kitab kumpulan hadith yang disusun oleh Imam al-Nawawi, sedangkan Bulūgh al-Marām Min Adillat alAḥkām merupakan kitab kumpulan hadith-ḥadith hukum yang dihimpun oleh Ibnu Hajar al-Asqalani. Adapun literatur yang digunakan dalam kajian Ilmu Hadith adalah Baiqūniyah dan Manhal al-Latîf. Al-Manzūmah al-Baiqūniyah merupakan kitab musthalah karya Thaha bin Muhammad al-Fattuh al-Baiquni yang disajikan dalam bentuk bait syi'ir sebanyak 34 bait berisi topik topik utama dalam ilmu musthalah. Al-Manhal al-Latif Fì Ușul al-Hadith al-Sharif karya Muhammad bin Alawi bin Abbas al-Maliki al-Hasani merupakan literatur dalam ilmu hadith yang mencakup pembahasan-pembahasan tentang ilmu musthalah bagi pemula dari sisi kaidah, sejarah dan periwayatannya. Literatur wajib tersebut bisanya digunakan oleh pesantren mu'ädalah dan mendapatkan legalisasi ijazahnya.

Perkembangan literatur hadith di pesantren Kabupaten Banyumas dapat dilihat melalui beberapa sampel pesantren beserta literatur hadith yang digunakan di madrasah diniyah masing-masing. ${ }^{25}$ :

\begin{tabular}{|c|c|c|c|}
\hline No & Nama Pesantren & Lokasi & $\begin{array}{c}\text { Literatur Hadith/Ilmu Hadith } \\
\text { yang Digunakan }\end{array}$ \\
\hline 1. & Al-Faruq & Karanglewas & $\begin{array}{l}\text { - al-Arba'īn al-Nawawiyah } \\
\text { - Bulūgh al-Marām }\end{array}$ \\
\hline 2. & Raudhatul Ulum & Kedungbanteng & $\begin{array}{l}\text { - Al-Manzūmah al- } \\
\text { Baiqūniyah }\end{array}$ \\
\hline 3. & Fathul Mu'in & Kedungbanteng & 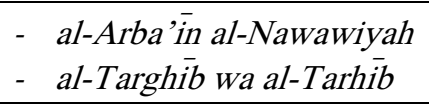 \\
\hline 4. & Darul Ulum & Kemanjren & - al-Arba'in al-Nawawiyah \\
\hline
\end{tabular}

${ }^{24}$ Dokumentasi aturan Kementrian Agama tentang penyetaraan ijazah pondok pesantren, PD Pontren Kantor Kementrian Agama Kabupaten Banyumas.

${ }^{25}$ Data pemutakhiran pondok pesantren bagian PD Pontren Kantor Kemenag Banyumas 2015 dan wawancara dengan beberapa pengajar madrasah diniyah masingmasing pesantren. 


\begin{tabular}{|c|c|c|c|}
\hline No & Nama Pesantren & Lokasi & $\begin{array}{c}\text { Literatur Hadith/Ilmu Hạadith } \\
\text { yang Digunakan }\end{array}$ \\
\hline & & & $\begin{array}{ll}\text { - } & \text { Bulūgh al-Marām } \\
\text { - } & \text { Riyậ̣ al-Sāliḥīn } \\
\end{array}$ \\
\hline 5. & Raudhatul Ulum & Kemranjen & - Riyāọ al-Ṣāliḥin \\
\hline 6. & Al-Taujieh al-Islamy & Kebasen & $\begin{array}{l}\text { - } \quad \text { al-Arba'in al-Nawawiyah } \\
\text { - } \text { Bulügh al-Maräm } \\
\text { - } \text { Al-Targhib wa al-Tarhīb }\end{array}$ \\
\hline 7. & Darussa'adah & Tambak & 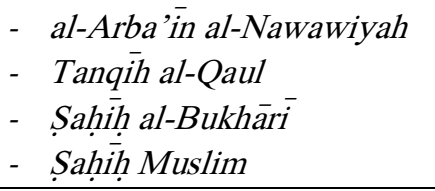 \\
\hline 8. & Hidayah al-Fattah & Karangrau & - S Sahịh al-Bukhārī \\
\hline 9. & Al-Thalabah & Karangrau & $\begin{array}{l}\text { - } \text { al-Arba'in al-Nawawiyah } \\
\text { - } \text { al-Adhkār } \\
\text { - } \text { Bulügh al-Marām }\end{array}$ \\
\hline 10. & Darul Huda & Pekuncen & $\begin{array}{ll}\text { - } & \text { Riyāọ al-Sälihīin } \\
\text { - } & \text { Bulūgh al-Marām } \\
\text { - } & \text { Mukhtär al-Ahādith }\end{array}$ \\
\hline 11. & $\begin{array}{l}\text { Pondok Modern } \\
\text { Miftahussalam }\end{array}$ & Banyumas & $\begin{array}{l}\text { - Muștalah Hadith Li al- } \\
\text { Shaikh al-Uthaimin } \\
\text { - } \text { Bulūgh al-Marām }\end{array}$ \\
\hline 12. & $\begin{array}{l}\text { Pondok Modern Dar } \\
\text { al-Qur'an al-Karim }\end{array}$ & Baturraden & $\begin{array}{c}\text { - } \quad \text { Taisir Muștalah al-Hadith } \\
\text { - } \quad \text { al-Arba'in al-Nawawiyah }\end{array}$ \\
\hline 13. & Al-Najah & Baturraden & 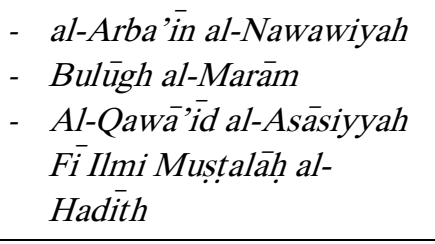 \\
\hline 14. & Manba'ul Ulum & Sumbang & $\begin{array}{l}\text { - } \quad \text { al-Arba'in al-Nawawiyah } \\
\text { - } \quad \text { Tanqih al-Qaul } \\
\text { - } \quad \text { Durrat al-Nāsihīin } \\
\text { - } \quad \text { Salāsahah al-Rasāil }\end{array}$ \\
\hline
\end{tabular}




\begin{tabular}{|c|c|c|c|}
\hline No & Nama Pesantren & Lokasi & $\begin{array}{c}\text { Literatur Hadith/Ilmu Hadith } \\
\text { yang Digunakan }\end{array}$ \\
\hline 15. & Al-Thohiriyah & Purwokerto Barat & 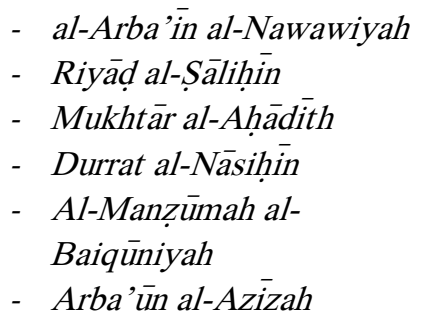 \\
\hline 16. & Darul Abror & Purwokerto Utara & 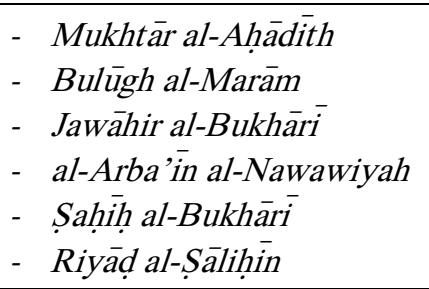 \\
\hline 17. & Al-Amin & Purwokerto Utara & $\begin{array}{ll}\text { - } & \text { al-Arba'in al-Nawawiyah } \\
\text { - } & \text { Durrat al-Näsihịn } \\
\text { - } & \text { Al-Targhib wa al-Tarhīb } \\
\text { - } & \text { Taisir Musthalah al-Hadiṣ }\end{array}$ \\
\hline 18. & Al-Hidayah & Purwokerto Utara & 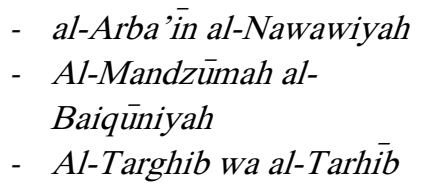 \\
\hline 19. & Darussalam & Kembaran & 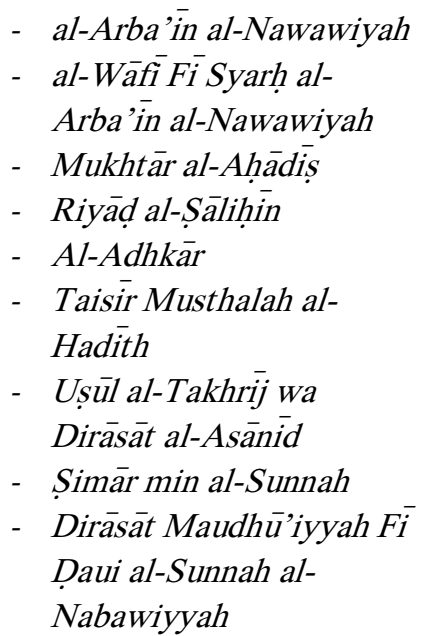 \\
\hline
\end{tabular}


Dari tabel di atas dapat dipetakan literatur hadith yang banyak digunakan di pesantren antara lain:

1. Al-Arba'in al-Nawawiyah digunakan oleh 14 pesantren

2. Bulügh al-Marām digunakan oleh 8 pesantren

3. Riyạ̄ al-Säliḥin digunakan oleh 6 pesantren

4. Mukhtār al-Ahàdīth dan Al-Targhib wa al-Tarhīb masing-masing digunakan oleh 4 pesantren

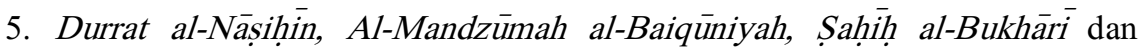
Taisir Musthalah al-Hadith masing-masing digunakan oleh 3 pesantren

6. Tanqīh al-Qaul dan al-Adhkär digunakan oleh 2 pesantren

7. Musthalah Hadith Li al-Shaikh al-Uthaimin, Arba' $\bar{U}$ al-Azizah, al-Wäfī Fì Sharh al-Arba'īn al-Nawawiyah, Jawāhir al-Bukhāri, Ușūl al-Takhrīj wa Dirāsāt al-Asānīd, Șimār min al-Sunnah, Dirāsāt Maựùiyyah Fì Daui alSunnah al-Nabawiyyah, Salāsah al-Rasāìl, Shahih Muslim, Al-Qawā'īd alAsāsiyyah Fì Ilmi Muștalạ̣̄ al-Hadith masing-masing digunakan oleh 1 pesantren.

Literatur hadith primer seperti kutub al-sittah nampaknya tidak terlalu banyak dikaji secara mendalam khususnya di pesantren modern. Dua kitab Sahịh milik al-Bukhari dan Muslim digunakan hanya oleh sebagian kecil pesantren. Seleksi hadith Sahịh al-Bukhari yang dijadikan referensi kurikulum salah satu pesantren adalah kitab Jawāhir al-Bukhārī karya Musthafa M. Umarah.

Literatur kumpulan hadith klasik yang banyak digunakan adalah AlArba'in al-Nawawiyah karya Imam Nawawi dan menempati urutan pertama dalam penggunaannya. Hal ini dapat dilihat dari 19 pesantren yang berhasil dikumpulkan datanya oleh penulis, 14 diantaranya menggunakan literatur tersebut. Kepopuleran kitab ini nampaknya disebabkan beberapa faktor, antara lain: kitab ini termasuk ke dalam kitab standar yang mudah untuk dikaji di berbagai tipe pesantren dengan hanya memuat empatpuluhan hadith. Faktor lainnya adalah kitab ini dipandang cukup komprehensif yang mencakup berbagai macam permasalahan penting agama. Literatur lain yang digunakan adalah Bulügh al-Marām karya Ibnu Hajar al-Asqalani dan telah diterjemahkan ke dalam bahasa Indonesia maupun bahasa Jawa serta Riyāọ al-Săliḥ̄in karya Imam al-Nawawi yang berisi tentang hadith-ḥadith amal shalih dan ibadah dengan diperkuat oleh ayat-ayat al-Qur'an terkait masing-masing tema. Selain itu terdapat kitab al-Adhkār karya Imam al-Nawawi, yang merupakan kitab kumpulan doa. Kitab ini menjadi salah satu kitab rujukan terkait tentang doa 
dan dzikir yang populer di dunia Islam, memuat sekitar 1324 Doa dan Dzikir. Kitab Durrat al-Năsihīin karya Usman bin Hasan al-Khubuwi berisi hadithhadith kisah maupun hikmah ibadah. Kitab Mukhtär al-Ahādith sebuah kitab kumpulan hadith karya Ahmad Hasyimi Bak juga digunakan serta kitab alTarghib wa al-Tarhib karya al-Hafidz al-Mundziri.

Syarah Hadith yang digunakan seperti Tanqīh al-Qaul al-ḥașiṣ Fi Sharḥ Lubāb al-Hadìth karya Nawawi al-Bantani serta al-Wäfi Fi Sharh al-Arba'īn alNawawiyah karya Muhammad Musthafa al-Bugha yang termasuk syarah hadith kontemporer dan komprehensif. Penulis al-Wăfī banyak mengambil istinbath hukum dari hadith-ḥadith karya imam Nawawi ini.

Dua literatur hadith tematik kontemporer digunakan di salah satu pesantren yaitu Thimār min al-Sunnah karya Sa'id Muhammad Shalih Shawabi yang memuat hadith-ḥadith pilihan dari berbagai kitab hadith primer. Kumpulan hadith tersebut dijelaskan menggunakan metode tematik. Tema-tema yang terkandung dalam buku ini berkenaan dengan masalah akhlak, keutamaan ilmu, tauhid dan ibadah. Kedua, Dirāsät Maựūiyyah Fì Daui al-Sunnah alNabawiyyah karya Marwan Muhammad Mustafa Syahin yang banyak memuat hadith-hadith hukum dan akhlak.

Penggunaan literatur ilmu hadith sudah dikembangkan oleh beberapa pesantren baik menggunakan literatur klasik seperti al-Manzūmah alBaiqūniyah karya Thaha bin Muhammad al-Fattuh al-Baiquni atau literatur kontemporer seperti Muștalah Hadith Li al-Shaikh al-Uthaimin, Taisir

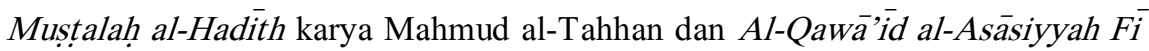
Ilmi Muștalāh al-Hadith karya Muhammad bin Alawi al-Maliki.

Adapun literatur metode penelitian atau studi kritis terhadap hadith, masih sangat jarang. Hanya ada satu pesantren saja yang menggunakan. Literatur tentang metode pemahaman hadith kontemporer belum ditemukan di 19 pesantren tersebut, namun berdasarkan wawancara dengan beberapa pengajar dan santri literatur itu diperkenalkan di sela-sela pembelajaran Ilmu Musthalah Hadis maupun pada saat menerangkan tentang matan hadith.

Jika dilihat dari tipe pesantren, beberapa pesantren klasik masih konsisten menggunakan literatur klasik atau yang lebih dikenal dengan istilah kitab kuning sebagai rujukannya, bahkan pesantren kategori modern yang mengintegrasikan antara kurikulum pesantren dan sekolah formal masih banyak yang menjadikan literatur-literatur klasik tersebut sebagai referensi dalam kurikulum pesantrennya dipadukan dengan buku paket Kementerian Agama. Dua pesantren dengan tipe modern sudah memasukkan literatur hadith maupun ilmu hadith kontemporer. Pesantren dengan tipe komprehensif dalam tulisan ini 
terbagi menjadi dua. Pertama, masih konsisten dengan penggunaan literatur klasik, kedua memadukan antara literatur klasik dan modern. Background santri yang berasal dari kalangan mahasiswa sebagai dampak positif dari program pesantrenisasi yang diadakan oleh IAIN Purwokerto, pengasuh pondok pesantren dengan background pendidikan formal tinggi serta tenaga pengajar yang banyak berasal dari unsur pendidik di perguruan tinggi maupun berpendidikan formal minimal S1 atau alumni Timur Tengah sangat berpengaruh secara signifikan terhadap perkembangan literatur hadith baik riwayah maupun dirayah khususnya literature hadith kontemporer di kalangan pesantren.

\section{Kesimpulan}

Dari pembahasan di atas dapat disimpulkan bahwa:

1. Perkembangan literatur hadith di pesantren wilayah Banyumas dapat dikatakan berjalan cukup lambat. Sebagian besar madrasah diniyah yang berada di pesantren masih belum menyentuh ke arah pemikiran baru atau mengadopsi literatur yang berorientasi metodologis layaknya pesantren salaf. Literatur yang diajarkan sebagian besar masih buku-buku karangan ulama klasik atau yang disebut dengan kitab kuning, meski sebagian pesantren dengan tipe modern dan komprehensif sudah menambahkan literatur kontemporer dalam kurikulumnya.

2. Background santri yang berasal dari kalangan mahasiswa, pengasuh dengan pendidikan formal tinggi maupun tenaga pengajar dengan kualifikasi pendidikan minimal S1, alumni Timur Tengah atau berasal dari kalangan pendidik di perguruan tinggi memberikan pengaruh yang cukup signifikan terhadap perkembangan literatur hạa $\bar{i}$ th tersebut.

\section{Daftar Pustaka}

Al-Attas, S. M. N. Raniry and Wujudiyah of 17th Century Acheh. Singapore: MBRAS, 1966.

van Bruinessen, Martin. Kitab Kuning Pesantren dan Tarekat: Tradisi-tradisi Islam di Indonesia. Bandung: Mizan, 1995.

Departemen Agama RI Direktorat Jenderal Kelembagaan Agama Islam, Direktorat Pendidikan Keagamaan dan Pondok Pesantren Proyek Peningkatan Pendidikan Luar Sekolah pada Pondok Pesantren. Pola Pengembangan Pondok Pesantren, Jakarta, 2003. 
Direktorat Jenderal Pembinaan Kelembagaan Agama Islam Departemen Agama Islam RI. Sejarah Institut Agama Islam Negeri tahun 1976-1980. Proyek Pembinaan Prasarana dan Sarana Perguruan Tinggi Agama/IAIN di Jakarta, 1986

. Rumusan Orientasi Pengembangan Kurikulum Sistem Kredit Semester Institut Agama Islam Negeri (IAIN) 20-24 Agustus 1986 di Tugu Bogor,

-----------. Topik Inti Kurikulum Nasional Perguruan Tinggi Agama Islam Fakultas Usuluddin. Direktorat Pembinaan Kelembagaan Agama Islam Departemen Agama RI, 1998.

---------. "Kurikulum dan Silabus Institut Agama Islam Negeri.” SK. Menteri Agama RI No. 97 tahun, 1982.

----------. Proyek Pembinaan Prasarana dan Sarana Perguruan Tinggi Agama/IAIN di Jakarta, 1983/1984.

Dhofier, Zamakhsyari. Tradisi Pesantren: Studi Pandangan Hidup Kiai dan Visinya Mengenai Masa Depan Indonesia. Jakarta: LP3ES, 2011.

Madjid, Nurcholish. Bilik-bilik Pesantren Sebuah Potret Perjalanan. Jakarta: Paramadina, 1997.

Mahfudz, Sahal. Pesantren Mencari Makna. Jakarta: Pustaka Ciganjur, 1999.

Mansur. Moralitas Pesantren, Meneguk Kearifan dari Telaga Kehidupan. Yogyakarta: Safiria Insania Press, 2004.

Mas'ud, Abdurrahman. Intelektual Pesantren: Perhelatan Agama dan Tradisi. Yogyakarta: LKiS, 2004.

Mastuhu. Dinamika Sistem Pendidikan Pesantren. Jakarta: INIS, 1994.

al-Pariswani, Abdullah bin Yasin. Ziyat al-Ta'liquàt, Maktabah al-Turāth alIslāmi, tth.

Qomar, Mujamil. T.th, Pesantren: Dari Transformasi Menuju Demokratisasi Institusi. Jakarta: Erlangga, tth.

Rahim, Husni. Madrasah dalam Politik Pendidikan Indonesia. Ciputat: PT Logos Wacana Ilmu, 2005.

Rahman, Asimuni A. dkk. Kurikulum (Manhaj al-Dirasah) Fakultas Syariah IAIN Sunan Kalijaga. Yogyakarta: Fakultas Syariah, 1971.

Saridjo, Marwan et. al. Sejarah Pondok Pesantren di Indonesia. Jakarta: Dharma Bakti, 1982.

Steenbrink, Karel A. Pesantren, Madrasah Sekola: Pendidikan dalam Kurun Modern. Jakarta: LP3ES, 1986

Sunanto, Musyrifah. Sejarah Peradaban Islam Indonesia. Jakarta: PT. Raja Grafindo Persada, 2007. 
Tholkhah, Imam dan Ahmad Barizi. Membuka Jendela Pendidikan, Mengurai Akar Tradisi. Jakarta: PT. Raja Grafindo Persada, 2004.

Wahid, Abdurrahman. Bunga Rampai Pesantren. Jakarta: Dharma Bhakti, 1978.

Yunus, Mahmud. Sejarah Pendidikan Islam di Indonesia. Jakarta: Mutiara Sumber Widya, 1985. 